\title{
KESEJAHTERAAN PETANI PELAKU USAHATANI POLIKULTUR TERINTEGRASI DI KABUPATEN TASIKMALAYA
}

\section{THE WELFARE OF INTEGRATED POLYCULTURAL FARMERS IN TASIKMALAYA DISTRICT}

\author{
Rina Nuryati1*1, Lies Sulistyowati ${ }^{2}$, Iwan Setiawan ${ }^{2}$, Trisna Insan Noor ${ }^{2}$ \\ ${ }^{1}$ Fakultas Pertanian Universitas Siliwangi, Jl. Siliwangi No. 24 Tasikmalaya \\ ${ }^{2}$ Fakultas Pertanian dan Sekolah Pascasarjana UNPAD, Jl. Raya Jatinangor Sumedang \\ *E-mail corresponding: rinanuryati@unsil.ac.id \\ (Diterima 27-03-2019; Disetujui 19-07-2019)
}

\begin{abstract}
ABSTRAK
Indonesia memiliki potensi lahan kering (LK) yang luas yang umumnya berstatus kritis dan terdapat di desa tertinggal yang sebagian besar dikelola petani miskin yang tidak mampu melaksanakan upaya konservasi, sehingga kondisinya memburuk. Pola pengembangan pertanian yang sesuai dengan karakteristik LK adalah usahatani terintegrasi. Usahatani terintegrasi memiliki tiga fungsi pokok, yaitu memperbaiki kesejahteraan dan mendorong pertumbuhan ekonomi, ketahanan pangan dan memelihara keberlanjutan lingkungan. Kesejahteraan keluarga petani merupakan output dari proses pengelolaan sumberdaya dan penanggulangan masalah yang dihadapi keluarga petani. Penelitian bertujuan untuk mengetahui kesejahteraan petani pelaku UTPPT. Penelitian dilakukan dengan metode survey terhadap 250 orang petani di Kabupaten Tasikmalaya yang diambil secara proportional random sampling. Data dianalisis dengan analisis struktur pendapatan dan struktur pengeluaran/konsumsi pangan rumah tangga petani, serta Nilai Tukar Pendapatan Rumahtangga Pedesaan (NTPRP). Hasil penelitian menunjukkan bahwa pendapatan rumah tangga petani bersumber dari sektor pertanian dan non pertanian serta dari pendapatan anggota keluarga. Pendapatan dari sektor pertanian diperoleh dari usahatani polikultur (tanaman kehutanan, perkebunan, hortikultura dan pangan) dan usaha ternak. Kontribusi pendapatan usahaternak lebih besar $(37,99 \%)$ dari pada usahatani polikultur $(35,52 \%)$ dan non pertanian $(26,49 \%)$, serta pendapatan anggota keluarga $(7,91 \%)$. Pendapatan dari UTPPT penyumbang terbesar pendapatan rumah tangga petani. Sebanyak $71,46 \%$ keluarga petani proporsi pendapatan dari sektor pertanian $>80 \%$. Sebanyak $63,67 \%$ petani menggantungkan hidup sepenuhnya dari sektor pertanian. Pangsa pengeluaran pangan rumah tangga petani masih cukup tinggi, 42,19\% keluarga petani pengeluaran untuk pangannya antara $60-80 \%$ dan $>80 \%$. NTPRP bernilai $>1$, petani mengalami surplus sehingga termasuk kategori sejahtera.
\end{abstract}

Kata kunci: Usahatani Polikultur Perkebunan Terintegrasi, NTPRP, Pangsa Pengeluaran Pangan

\section{ABSTRACT}

Indonesia has the potential for extensive dry land (LK) that was generally in critical status and are located in disadvantaged villages, most of which are managed by poor farmers who are unable to carry out conservation efforts, so that their conditions deteriorate. The pattern of agricultural development in accordance with the characteristics of FIs is integrated farming. Integrated farming has three main functions, namely improving welfare and encouraging economic growth, food security and maintaining environmental sustainability. The well-being of the farm family is the output of the resource management process and overcoming the problems faced by the farmer family. The study aims to determine the welfare of farmers who are UTPPT actors. Research was done by using survey method of 250 farmers in Tasikmalaya Regency that was determined by proportional random sampling. Data were analyzed by analysis of income structure and expenditure structure/consumption of farmer $R T$ food, as well as the exchange rate of rural household income (NTPRP). The results of the study shows that the income of farmer households comes from the agricultural and non-agricultural sectors as well as from the income of family 


\section{KESEJAHTERAAN PETANI PELAKU USAHATANI POLIKULTUR TERINTEGRASI \\ DI KABUPATEN TASIKMALAYA \\ Rina Nuryati, Lies Sulistyowati, Iwan Setiawan, Trisna Insan Noor}

members. Revenues from the agricultural sector are obtained from polyculture farming (forestry, plantation, horticulture and food) and livestock business. The contribution of livestock business income is greater (37.99\%) than polyculture farming (35.52\%) and non-agricultural (26.49\%) and family member income (7.91\%). Income from UTPPT is the biggest contributor to farmer household income. A total of $71.46 \%$ of farmer families share the income from the agricultural sector $>80 \%$. As many as $63.67 \%$ of farmers depend entirely on the agricultural sector. The share of food expenditure for farmer households is still quite high, 42.19\% of farmer households spend between $60-80 \%$ and $>80 \%$ on food. NTPRP has a value of $>1$, farmers experience a surplus which includes the category of prosperity.

Keywords: Integrated Plantation Farming Polyculture, NTPRP, Food Expenditure Share

\section{PENDAHULUAN}

Pembangunan pertanian selama ini banyak ditujukan pada upaya peningkatan ketersediaan pangan nasional melalui optimalisasi lahan sawah. Hal ini perlu diwaspadai karena luas lahan sawah mengalami penurunan akibat terjadinya alih fungsi kegiatan menjadi non-pertanian dan proses degradasi lahan yang terus berlangsung. Di sisi lain, lahan kering kurang mendapatkan prioritas pada program peningkatan produksi pertanian. Bahkan, pembangunan pertanian di lahan kering jauh tertinggal dibandingkan dengan pembangunan pertanian di lahan sawah.

Panadji (2013) menyatakan lahan kering adalah bagian kedaulatan, asset negara dan masyarakat, yang tidak dapat diremehkan. Negara akan mengalami kelumpuhan (pangan, energi, ekonomi, tempat tinggal dan jasa lingkungan) ketika perhatian terhadap lahan kering terabaikan. Krisis pangan, energi, ekonomi, tempat tinggal, dan jasa lingkungan adalah cermin kelemahan dan keburukan pengelolaan lahan kering di Indonesia selama empat dekade terakhir. Investasi negara untuk pengembangan lahan kering (untuk masyarakat kecil dan petani) sangat rendah, sehingga lahan kering yang dikelola masyarakat petani mengalami defisiensi multi dimensi (infrastruktur, energi, entrepreneurship and brain power dan modal sosial).

Akibat bias kebijakan pembangunan ekologi masyarakat lahan kering secara umum menunjukkan gambaran relatif buruk dibandingkan (misalnya) dengan ekologi lahan basah (sawah). Argoekologi lahan kering, terutama di daerah perbukitan atau kawasan "menara air" alami, mengalami kerusakan yang relatif besar dibandingkan dengan lahan basah di dataran rendah. Demikian juga dengan kondisi masyarakatnya; masyarakat pertanian pedesaan lahan kering 
umumnya mengalami marjinalisasi yang lebih parah dibandingkan dengan masyarakat di lahan sawah (Panadji, 2005a).

World Bank (1999) menyatakan, lahan kering merupakan lahan marjinal yang dicirikan dengan tingkat kesuburan yang rendah (defisiensi nutrisi, keasaman, salinitas dan kapasitas kelembaban yang rendah). Masyarakatnya tidak mempunyai aksesibilitas terhadap komunikasi, tidak mempunyai mobilitas terhadap aspek sosial dan ekonomi, rapuh (kapasitas penyerapan input yang rendah, kapasitas bertahan terhadap gangguan terbatas, kondisi lahan mudah rusak sampai kerusakan yang tidak dapat dirubah) dan heterogen, keragaman fisik dan budaya dengan kendala yang spesifik dan peluang penerapan teknologi secara umum terbatas atau kurangnya kelembagaan untuk meniadakan kendala atau memanfaatkan peluang.

Indonesia memiliki potensi lahan kering yang merupakan lahan pertanian marjinal yang relative luas namun belum dimanfaatkan dan belum dikelola dengan baik. Luas lahan kering yang memungkinkan untuk pengembangan pertanian menurut Pusat Penelitian dan Pengembangan Tanah dan Agroklimat
(2001) mencapai 75,1 juta ha. Lebih rinci, Abdurachman et al (2005) menjelaskan bahwa dari total luas lahan kering 148 juta ha, yang sesuai untuk budidaya pertanian sekitar 76,22 juta ha (52 persen), sebagian besar terdapat di dataran rendah $(70,71$ juta ha atau 93 persen) dan sisanya di dataran tinggi (5,51 juta ha atau 7 persen). Di wilayah dataran rendah, lahan datar sampai bergelombang (lereng $<15$ persen) yang sesuai untuk tanaman pangan mencakup 23,26 juta ha sedang pada lahan dengan lereng 15-30 persen lebih seusai untuk tanaman tahunan (47,45 juta ha). Di dataran tinggi, lahan yang sesuai untuk tanaman pangan hanya sekitar 2,07 juta ha dan untuk tanaman tahunan 3,44 juta ha.

Karama dan Abdurrachman (1995) menyatakan bahwa lahan kering marginal yang berstatus kritis umumnya terdapat di wilayah desa tertinggal dan sebagian besar dikelola oleh petani miskin yang tidak mampu melaksanakan upaya-upaya konservasi, sehingga kondisinya makin lama makin memburuk. McLeod dan Rahmianna (2009) mengemukakan bahwa lahan kering merupakan salah satu sumberdaya lahan yang memiliki potensi besar untuk pembangunan pertanian, baik tanaman pangan, hortikultura, 


\section{KESEJAHTERAAN PETANI PELAKU USAHATANI POLIKULTUR TERINTEGRASI \\ DI KABUPATEN TASIKMALAYA \\ Rina Nuryati, Lies Sulistyowati, Iwan Setiawan, Trisna Insan Noor}

perkebunan dan peternakan. Abdurahman et al (1997) menjelaskan bahwa pola pengembangan pertanian yang sesuai dengan karakteristik dan keterbatasan yang ada pada lahan kering adalah usahatani terintegrasi. Andriani et al (2012) menyatakan bahwa usahatani terintegrasi dapat menjadi pilihan karena sistem usahatani ini memiliki tiga fungsi pokok, yaitu memperbaiki kesejahteraan dan mendorong pertumbuhan ekonomi serta ketahanan pangan, dan juga berfungsi dalam memelihara keberlanjutan lingkungan.

Sunarti dan Khomsan (2006) dalam Siswati dan Nizar (2014), menjelaskan bahwa kesejahteraan keluarga petani merupakan output dari proses pengelolaan sumberdaya keluarga dan penanggulangan masalah yang dihadapi keluarga petani. Priyantini (2007) menyebutkan bahwa petani yang melaksanakan kegiatan integrasi tanaman dengan ternak memiliki kinerja ekonomi rumah tangga yang lebih baik dibandingkan dengan petani yang tidak mengikuti pola tersebut.

Namun demikian, fenomena kemiskinan di kalangan petani saat ini masih banyak ditemukan. Kemampuan sektor pertanian dalam hal ini usahatani terintegrasi untuk memberikan kontribusi secara langsung terhadap pertumbuhan ekonomi dan kesejahteraan rumah tangga petani perlu dikaji lebih lanjut, berkenaan dengan Departemen Pertanian (2003) yang menyatakan bahwa pertanian di Indonesia sampai saat ini masih didominasi oleh usahatani kecil dengan tingkat pendidikan rendah (81 persen dari 40 juta tenaga kerja pertanian berpendidikan SD ke bawah), berlahan sempit, bermodal kecil dan memiliki produktivitas yang rendah. Sempitnya penguasaan lahan oleh petani sekitar 0,3 $0,5 \mathrm{ha} / \mathrm{kk}$ adalah sesuatu hal yang sangat sulit bagi petani di Jawa untuk memperoleh penghasilan dan kehidupan yang layak dari sumberdaya lahannya (Utomo, 2012).

Penelitian ini dilakukan dengan tujuan untuk mengkaji kesejahteraan rumah tangga petani pelaku usahatani polikultur terintegrasi di Kabupaten Tasikmalaya. Pembahasan difokuskan pada kajian struktur pendapatan dan struktur pengeluaran rumah tangga petani serta nilai tukar pendapatan rumah tangga pedesaan (NTPRP). Penelitian diharapkan bermanfaat sebagai bahan masukan dalam penyusunan kebijakan peningkatan kesejahteraan petani yang memerlukan data dan informasi di tingkat mikro supaya dapat memotret kondisi 
terkini mengenai tingkat pendapatan rumah tangga petani di perdesaan, baik yang bersumber dari usahatani, non usahatani, dan pendapatan anggota keluarga, sehingga dapat diketahui gambaran umum mengenai tingkat kesejahteraan petani sebagai komunitas perdesaan.

\section{METODE PENELITIAN}

Penelitian dilaksanakan di Kabupaten Tasikmalaya yang difokuskan di 2 kecamatan, yaitu Kecamatan Cibalong dan Kecamatan Karangnunggal. Dari masing-masing kecamatan diambil 2 desa, yaitu Desa Parung dan Setiawaras untuk Kecamatan Cibalong, dan Desa Cikupa serta Ciawi untuk Kecamatan Karangnunggal.

Sumber data yang digunakan untuk mengkaji kesejahteraan petani pelaku usahatani terpadu adalah data primer dari petani yang menjadi responden. Pengumpulan data yang diperlukan dilakukan melalui survey yang melibatkan 250 rumah tangga petani dengan rincian dapat dilihat pada Tabel 1.

Tabel 1. Jumlah Petani Responden Masingmasing Lokasi Penelitian

\begin{tabular}{|c|c|c|c|c|}
\hline No & Kecamatan & Desa & $\begin{array}{c}\text { Populasi } \\
\text { (orang) }\end{array}$ & $\begin{array}{l}\text { Sampel } \\
\text { (orang) }\end{array}$ \\
\hline \multirow[t]{2}{*}{1} & Cibalong & Parung & 1.569 & 44 \\
\hline & & Setiawaras & 4.369 & 123 \\
\hline \multirow[t]{3}{*}{2} & Karangnunggal & Cikupa & 2.115 & 59 \\
\hline & & Ciawi & 838 & 24 \\
\hline & Jumlah & & 8.981 & 250 \\
\hline
\end{tabular}

Analisis data dilakukan dengan menggunakan rumus sebagai berikut:

\section{1) Struktur pendapatan rumah tangga petani}

Struktur pendapatan rumah tangga petani dari sektor pertanian secara sederhana dapat dirumuskan menurut Nurmanaf (2005) sebagai berikut:

$\mathrm{PPSP}=\sum\left(\mathrm{TPSP} / \sum \mathrm{TP}\right) \times 100 \%$

Keterangan:

PPSP $=$ Pangsa pendapatan sektor pertanian (\%)

TPSP $=$ Total pendapatan dari sektor pertanian (Rp/tahun)

$\mathrm{TP}=$ Total pendapatan rumah tangga petani (Rp/tahun)

\section{2) Struktur pengeluaran/ konsumsi} Pangan Rumah Tangga

Semakin besar pangsa pengeluaran untuk pangan menunjukkan bahwa pendapatan rumah tangga masih terkonsentrasi untuk memenuhi kebutuhan dasar. Sebaliknya, semakin besar pangsa pengeluaran sektor sekunder (non pangan), mengindikasikan telah terjadi pergeseran posisi petani dari subsisten ke komersial. Dalam arti, apabila kebutuhan primer telah terpenuhi, maka kelebihan pendapatan akan digunakan untuk memenuhi keperluan lain, seperti pendidikan, kesehatan, dan kebutuhan sekunder lainnya. 


\section{KESEJAHTERAAN PETANI PELAKU USAHATANI POLIKULTUR TERINTEGRASI \\ DI KABUPATEN TASIKMALAYA \\ Rina Nuryati, Lies Sulistyowati, Iwan Setiawan, Trisna Insan Noor}

Pangsa pengeluaran untuk pangan dihitung dengan rumus sebagai berikut:

$\mathrm{PEP}=\sum\left(\mathrm{PPn} / \sum \mathrm{TE}\right) \times 100 \%$

Keterangan:

$\mathrm{PEP}=$ Pangsa pengeluaran untuk pangan $(\%)$

PPn = Pengeluaran untuk pangan (Rp/tahun)

$\mathrm{TE}=$ Total pengeluaran rumah tangga petani ( $\mathrm{Rp} /$ tahun)

\section{3) Nilai Tukar Pendapatan} Rumahtangga Pedesaan (NTPRP)

Simatupang et al (2007) dalam Sugiarto (2008) menyatakan bahwa untuk mengukur kesejahteraan digunakan konsep Nilai Tukar Pendapatan Rumahtangga Pedesaan (NTPRP) yang merupakan perbandingan antara pendapatan total rumahtangga dengan pengeluaran total rumahtangga. Secara matematis konsep NTPRP dihitung dengan rumus sebagai berikut:

$$
\begin{aligned}
& \text { NTPRP }=Y / E \\
& Y=Y_{P}+Y_{N P} \\
& E=E_{P}+E_{K}
\end{aligned}
$$

Keterangan:

$$
\begin{aligned}
\mathrm{NTPRP}= & \text { Nilai tukar pendapatan } \\
& \text { rumahtangga pedesaan } \\
= & \text { Pendapatan } \\
\mathrm{Y}= & \text { Pengeluaran } \\
\mathrm{E}= & \text { Total pendapatan dari } \\
\mathrm{YP} & \text { usaha pertanian } \\
\mathrm{YNP}= & \text { Total pendapatan dari } \\
& \text { usaha non pertanian }
\end{aligned}
$$

$$
\begin{aligned}
\mathrm{EP}= & \text { Total pengeluaran untuk } \\
& \text { usaha pertanian } \\
\mathrm{EK} \quad= & \text { Total pengeluaran untuk } \\
& \text { usaha non pertanian }
\end{aligned}
$$

\section{HASIL DAN PEMBAHASAN}

\section{A. Karakteristik Petani}

Usia petani rata-rata antara 15-64 tahun yang merupakan usia yang masih termasuk pada produktif, diharapkan dapat menjamin petani dalam kondisi yang masih potensial dan produktif untuk mengelola usahataninya. Berdasarkan status perkawinannya, 90 persen berstatus kawin dan hanya sekitar 1,00-2,00 persen yang berstatus belum kawin dan berstatus duda/janda. Jumlah tanggungan keluarga paling banyak kurang dari 3 orang dan antara 3-5 orang. Jumlah petani yang memiliki tanggungan keluarga lebih dari 5 orang persentasenya hanya berkisar antara 2-3 orang. Tingkat pendidikan didominasi oleh petani yang berpendidikan SD mencapai lebih dari 50 persen.

Pekerjaan pokok responden pada umumnya adalah sebagai petani sehingga sektor pertanian sampai saat ini masih memegang peranan penting dalam mendukung perekonomian masyarakat. Pengalaman petani dalam pengelolaan usahatani polikultur terintegrasi sangat beragam mulai dari yang baru 1 tahun 
sampai yang sudah melaksanakannya selama lebih dari 40 tahun. Pengalaman petani yang baru 1 tahun pada kenyataannya mengelola usahataninya yang sudah berproduksi atau sudah menghasilkan. Hal ini disebabkan lahan usahatani yang dikelolanya merupakan lahan yang diperoleh dari orang tuanya berupa warisan. Asal pengetahuan usahatani polikultur terintegrasi, umumnya (lebih dari 60,00 persen) dari orang tuanya (warisan). Hal ini menunjukkan bahwa UTPPT merupakan usahatani yang sudah lama ditekuni oleh petani di lokasi penelitian.

Luas penguasaan lahan rata-rata 0,618 ha dengan status penguasaan lahan umumnya adalah lahan milik (lebih dari 90 persen) sehingga petani mendapatkan hak pengelolaan penuh terhadap lahan yang dimilikinya.

\section{B. Struktur Pendapatan Rumah Tangga Petani}

Sumber pendapatan yang biasa diperoleh rumahtangga di pedesaan menurut Ellis (2000) adalah: a) Sektor on farm income, yaitu pendapatan yang berasal dari pertanian baik dari lahan pertanian milik sendiri, maupun yang diusahakan oleh pemilik tanah maupun diakses melalui sewa menyewa ataupun bagi hasil; (2) Sektor off farm income, yaitu pendapatan yang diperoleh dari hasil di luar sektor pertanian tetapi masih dalam lingkup pertanian, diantaranya berasal dari upah tenaga kerja, sistem bagi hasil, maupun kontrak upah tenaga kerja non-upah; (3) Sektor non farm income, pendapatan yang bukan berasal dari pertanian, seperti pendapatan atau gaji pensiun, pendapatan dari usaha pribadi, dan sebagainya.

Tabel 2. Struktur Pendapatan Rumah Tangga Petani Polikultur Terintegrasi

\begin{tabular}{lcc}
\hline \multirow{2}{*}{ Sumber Pendapatan } & \multicolumn{2}{c}{ Kab. Tasikmalaya } \\
\cline { 2 - 3 } $\begin{array}{l}\text { Rupiah } \\
\text { Petani (Kepala } \\
\text { Keluarga) }\end{array}$ & & \\
\hline Subsektor Petanian & 5.081 .337 & 35.52 \\
\hline Subsektor Peternakan & 5.433 .443 & 37.99 \\
\hline Sektor Pertanian & 10.514 .780 & 73,51 \\
\hline Sektor Non Pertanian & 3.789 .398 & 26,49 \\
\hline $\begin{array}{l}\text { Total Pendapatan } \\
\text { Petani }\end{array}$ & 14.304 .178 & 92,09 \\
\hline $\begin{array}{l}\text { Kontribusi Anggota } \\
\text { Keluarga }\end{array}$ & 1.228 .634 & 7,91 \\
\hline & & \\
\hline $\begin{array}{l}\text { Pendapatan } \\
\text { Keluarga }\end{array}$ & & \\
\hline Subsektor Petanian & 5.081 .337 & 32,71 \\
\hline Subsektor Peternakan & 5.433 .443 & 34,98 \\
\hline Sektor Pertanian & 10.514 .780 & 67,69 \\
\hline $\begin{array}{l}\text { Sektor Non Pertanian } \\
\text { Total Pendapatan }\end{array}$ & 5.018 .032 & 32,31 \\
\hline $\begin{array}{l}\text { Keluarga } \\
\text { kendapatan per }\end{array}$ & 15.532 .812 & 100,00 \\
\hline
\end{tabular}

Tabel 2 menunjukkan bahwa pendapatan petani sebagai kepala keluarga bersumber dari pendapatan yang berasal dari sektor pertanian dan sektor non pertanian. Berkaitan dengan 


\section{KESEJAHTERAAN PETANI PELAKU USAHATANI POLIKULTUR TERINTEGRASI \\ DI KABUPATEN TASIKMALAYA \\ Rina Nuryati, Lies Sulistyowati, Iwan Setiawan, Trisna Insan Noor}

usahatani yang dikaji pada penelitian ini adalah usahatani polikultur terintegrasi, maka pendapatan dari sektor pertanian diperoleh dari usahatani polikultur berupa kombinasi dari tanaman kehutanan, tanaman perkebunan, tanaman hortikultura dan tanaman pangan serta pendapatan dari sektor peternakan. Sing dan Ratan (2009) menjelaskan bahwa sistem pertanian terintegrasi adalah seperangkat elemen atau komponen yang terintegrasi dari kegiatan yang diperlihatkan petani pada sumberdaya peternakan yang mereka miliki untuk memaksimalkan produktivitas dan pendapatan bersih usahatani secara berkelanjutan.

Mengkaji rata-rata luas pengelolaan lahan usahatani polikultur terintegrasi petani menunjukkan bahwa luas lahan UTPPT yang dikelola petani hanya mencapai 0,62 ha per petani. Lisson et al (2010) menjelaskan bahwa sistem usahatani Indonesia didominasi oleh petani kecil dengan kepemilikan lahan yang relatif sempit. Namun demikian, terdapat integrasi yang kuat di antara berbagai elemen biofisik yaitu tanaman, ternak dan tanah, serta adanya dukungan sumberdaya (kualitas dan kuantitas lahan, suplai pakan, tenaga kerja dan permodalan) dan dukungan faktor sosial (agama, budaya dan perilaku).

Turasih dan Wibowo menyatakan adanya kelangkaan sumber penghidupan yang memadai di perdesaan yang pada akhirnya menjadikan petani harus memilih untuk menerapkan strategi intensifikasi pada lahan pertanian yang dimilikinya atau melakukan strategi diversifikasi sumber nafkah. Kegiatan mendiversifikasi nafkah ini merupakan bentuk perjuangan rumah tangga petani dalam menghadapi berbagai situasi. Berkaitan dengan hal tersebut, dalam upaya meningkatkan pendapatannya, petani selain bekerja pada sektor pertanian juga berusaha di sektor non pertanian termasuk melibatkan anggota keluarganya untuk berkontribusi terhadap pendapatan rumah tangga petani.

Secara keseluruhan sektor pertanian memberikan kontribusi sebesar 73,51 persen terhadap pendapatan petani. Kontribusi terbesar diperoleh dari sektor peternakan (35,52 persen) dan dari tanaman polikultur (perkebunan, kehutanan dan tanaman semusim sebesar 37,99 persen. Dari sektor non pertanian memberikan kontribusi sebesar 26,49 persen dan dari pendapatan anggota keluarga sebesar 7,91 persen. Sektor pertanian memberikan kontribusi 
terhadap total pendapatan rumah tangga petani sebesar 67,69 persen dan sektor non pertanian sebesar 32,31 persen. Dengan demikian, sektor pertanian masih merupakan sektor yang memberikan kontribusi terbesar terhadap pendapatan rumah tangga petani. Hal ini sesuai dengan hasil kajian Susilowati dan Suryani (2000) yang menunjukkan bahwa sektor pertanian di pedesaan Jawa Tengah masih memberikan kontribusi pendapatan rumah tangga sebesar 73 persen dan sisanya bersumber dari pendapatan non pertanian.

Besarnya pendapatan dari sektor pertanian memperlihatkan besarnya peranan petani sebagai kepala keluarga untuk mensejahterakan keluarganya. Selain pendapatan dari sektor pertanian, dalam hal ini pendapatan dari usahatani terintegrasi, petani juga memperoleh pendapatan dari sektor non pertanian yaitu dari pekerjaannya sebagai buruh, wiraswasta dan sebagai PNS termasuk penyediaan jasa (ojek, penjahit dan sopir). Dalam upaya memenuhi kebutuhan keluarganya, maka anggota keluarga petani dilibatkan dalam mencari nafkah.

Dengan demikian, struktur pendapatan rumah tangga petani memperlihatkan dinamika dari aktivitas semua anggota keluarga petani pada kehidupan sehari-hari, baik pada aktivitas sektor pertanian maupun aktivitas di luar sektor pertanian dalam upaya memenuhi kebutuhan anggota keluarganya. Pendapatan yang berasal dari sektor non pertanian dan pendapatan anggota keluarga memiliki peranan penting bagi rumah tangga petani. Widodo (2006) mengungkapkan adanya gejala migrasi tenaga kerja sektor pertanian ke sektor non pertanian melalui proses migrasi desa-kota memberikan gambaran tentang usaha mempertahankan hidup melalui pencarian nafkah di luar sektor pertanian.

Kusnadi (2000) menyatakan bahwa dalam upaya memenuhi kebutuhan dasar kehidupan yang dihadapi rumah tangga, individu-individu yang ada dalam rumah tangga petani berusaha secara maksimal untuk dapat bekerja guna memenuhi kebutuhan rumah tangga agar kelangsungan hidupnya dapat terpelihara. Setiap anggota rumah tangga petani dapat memperoleh penghasilan yang berfungsi untuk menjaga kelangsungan hidup bersama. Pada situasi yang demikian, sistem pembagian kerja dilakukan secara fleksibel dan adaptif pada upaya pemenuhan kebutuhan hidup rumah tangga petani. Chambers dan Conway (1991) menyatakan bahwa mata 


\section{KESEJAHTERAAN PETANI PELAKU USAHATANI POLIKULTUR TERINTEGRASI \\ DI KABUPATEN TASIKMALAYA \\ Rina Nuryati, Lies Sulistyowati, Iwan Setiawan, Trisna Insan Noor}

pencaharian (livelihood) merupakan kemampuan, aset, dan aktivitas yang diperlukan sebagai alat untuk hidup. Penghasilan yang rendah dari sektor pertanian mendorong petani untuk mencari alternatif tambahan penghasilan guna memenuhi kebutuhan keluarganya. Upaya yang dilakukan diantaranya menjalani pola nafkah ganda (Sumarti, 2007).

Total pendapatan rumah tangga petani mencapai Rp 15.532.812 per tahun dengan pendapatan per kapita/bulan sebesar Rp 364.994. Data pendapatan per kapita per bulan tersebut dibandingkan dengan garis kemiskinan di pedesaan Jawa Barat pada tahun 2017 sebesar Rp 241.682 (BPS Jawa Barat, 2017), maka petani di Kabupaten Tasikmalaya secara umum tidak miskin walaupun relatif masih dekat dengan garis kemiskinan. Sehubungan dengan hal tersebut, maka diperlukan upaya untuk meningkatkan pendapatan rumah tangga petani agar dapat bergerak menjauhi garis kemiskinan untuk mencapai kesejahteraan.

Perhitungan pangsa pendapatan sektor pertanian (PPSP) (Tabel 3.) dalam struktur pendapatan keluarga petani, menunjukkan bahwa pendapatan dari sektor pertanian (Usahatani polikultur terintegrasi) sangat dominan sebagai penyumbang terbesar bagi pendapatan rumah tangga petani. Di lokasi penelitian sebanyak 71,46\% keluarga petani proporsi pendapatan dari sektor pertanian mencapai lebih dari $80 \%$. Hal ini memperlihatkan bahwa pada umumnya di lokasi penelitian, usahatani polikultur terintegrasi menjadi tulang punggung bagi sumber pendapatan rumah tangga.

$\begin{array}{lll}\text { Tabel } 3 & \begin{array}{l}\text { Pangsa } \\ \text { Pertanian }\end{array} & \begin{array}{c}\text { Pendapatan Sektor } \\ \text { (PPSP dalam \%) }\end{array} \\ & \text { Keluarga Petani }\end{array}$

\begin{tabular}{cc} 
Proporsi & Kab Tasikmalaya (\%) \\
\hline$<20 \%$ & 4,20 \\
\hline $21-40 \%$ & 9,92 \\
\hline $41-60 \%$ & 5,41 \\
\hline $61-80 \%$ & 9,01 \\
\hline$>80 \%$ & 71,46 \\
\hline Total & 100,00 \\
\hline \multicolumn{2}{c}{} \\
\hline$<100 \%$ & 36,33 \\
\hline $100 \%$ & 63,67 \\
\hline Total & 100,00 \\
\hline
\end{tabular}

Sebanyak 63,67 persen petani di Kabupaten Tasikmalaya menggantungkan hidup sepenuhnya dari sektor pertanian (Gambar 1). Hal ini semakin memperkuat bahwa sektor pertanian merupakan tulang punggung sumber pendapatan rumah tangga petani. Agustian dan Ilham (2008) menyebutkan bahwa struktur pendapatan rumah tangga tani masih dominan berasal dari sektor pertanian. Tahun 2004 pangsa 
pendapatan rumah tangga tani berbasis lahan sawah sekitar $51,33 \%$ berasal dari sektor pertanian, demikian juga dengan rumah tangga tani di desa-desa berbasis lahan kering sekitar 53,38\% sumber pendapatannya berasal dari sektor pertanian. Keadaan ini semakin memperkuat bahwa sektor pertanian masih tetap merupakan andalan bagi rumah tangga dalam membiayai hidup keluarga selain pendapatan tambahan dari non pertanian.

Total pendapatan keluarga petani per tahun di Kabupaten Tasikmalaya adalah Rp 15.532.812 atau setara dengan pendapatan per bulan sebesar Rp 1.294,401,0 (Gambar 2). Dibandingkan dengan upah minimum regional (UMR) Kabupaten Tasikmalaya tahun 2017 sebesar Rp 1.931.435 per bulan, maka sebagian besar petani di lokasi penelitian memperoleh pendapatan lebih rendah dari UMR. Hal ini memperlihatkan bahwa rata-rata petani yang bekerja di sektor pertanian (Usahatani polikultur terintegrasi) kehidupannya lebih miskin dibandingkan dengan yang bekerja di luar sektor pertanian. Hasil kajian Ilham (2009) juga menyimpulkan bahwa rumah tangga nonpertanian relatif lebih sejahtera dibandingkan dengan rumah tangga petani. Namun demikian rumah tangga nonpertanian lebih sensitif terhadap guncangan ekonomi seperti Kenaikan harga BBM dan harga beras yang menyebabkan penurunan kesejahteraan.

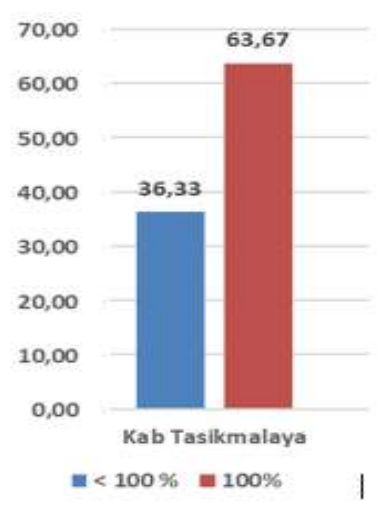

Gambar 1. Pangsa Pendapatan Sektor Pertanian (PPSP dalam \%) Kel. Petani

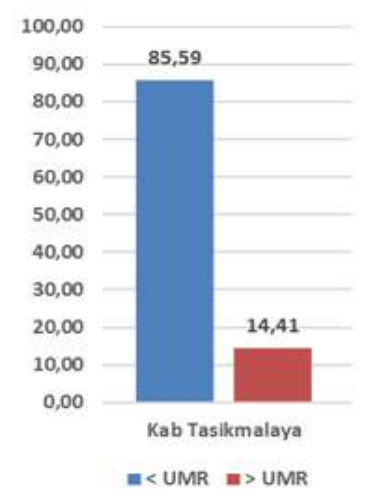

Gambar 2. Perbandingan Pendapatan Keluarga dgn UMR Kab.Tsm 2017 Rp 1.931.435/bln

\section{Struktur Pengeluaran Rumah Tangga Petani}

Kebutuhan rumah tangga dapat dikelompokkan dalam dua kategori, yaitu kebutuhan pangan dan non pangan. Pada tingkat pendapatan tertentu, rumah tangga akan mengalokasikan pendapatannya untuk memenuhi kedua kebutuhan 


\section{KESEJAHTERAAN PETANI PELAKU USAHATANI POLIKULTUR TERINTEGRASI \\ DI KABUPATEN TASIKMALAYA \\ Rina Nuryati, Lies Sulistyowati, Iwan Setiawan, Trisna Insan Noor}

tersebut. Kuantitas pangan yang dibutuhkan seseorang secara alamiah akan mencapai titik jenuh, sementara itu kebutuhan non pangan tidak dibatasi dengan cara yang sama. Sehubungan dengan itu, maka besaran pangan (yang diproksi dengan pengeluaran total) yang dibelanjakan untuk pangan pada suatu rumah tangga dapat dipakai sebagai petunjuk tingkat kesejahteraan rumah tangga yang bersangkutan. Pangsa pengeluaran pangan yang semakin tinggi berarti kesejahteraan rumah tangga yang bersangkutan semakin rendah, sebaliknya semakin kecil pangsa pengeluaran pangan maka rumah tangga tersebut makin sejahtera.

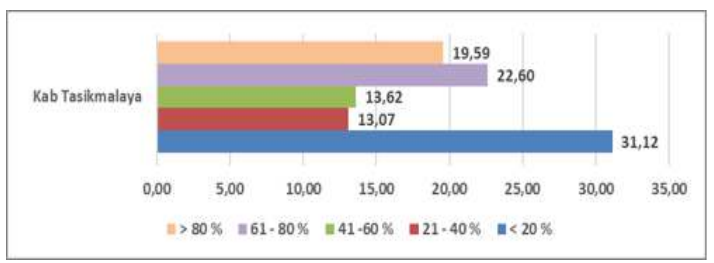

Gambar 3. Pangsa Pengeluaran untuk Pangan dari Total Konsumsi (PEP dalam \%) Keluarga Petani

Hal ini sesuai dengan Hukum Engle bahwa semakin tinggi pendapatan maka pangsa pengeluaran pangan semakin kecil. Pengeluaran pangan dengan pendapatan rumah tangga memiliki hubungan terbalik maksudnya makin rendah pendapatan rumah tangga maka semakin tinggi persentase pengeluaran pangan mereka (Pakpahan, 2011).
Rumah tangga akan terus menambah konsumsi makanannya seiring dengan meningkatnya pendapatan, dan sampai batas tertentu peningkatan pendapatan tidak lagi menyakibatkan bertambahnya jumlah makanan yang dikonsumsi.

Struktur pengeluaran rumah tangga petani pada penelitian ini dilihat dari total konsumsi yaitu pangsa pengeluaran pangan terhadap total pengeluaran termasuk biaya usahatani (konsumsi pangan, non pangan dan biaya usahatani). Gambar 3 memperlihatkan bahwa di Kabupaten Tasikmalaya 42,19\% keluarga petani melakukan pengeluaran untuk pangannya antara 60-80\% dan lebih dari $80 \%$. Sementara itu data FAO (2009) menunjukkan bahwa tahun 2006 pangsa pengeluaran pangan penduduk Indonesia secara agregat sebesar 47,9\%. Beberapa negara pangsa pengeluaran pangan rumah tangga secara nasional jauh di atas negara-negara maju diantaranya adalah negara Cina (39,8\%), Italia $(22,1 \%)$, Inggris (22,5\%), dan USA (13,7\%).

Sudaryanto et al (1999) menyatakan bahwa tingkat pendapatan memiliki hubungan yang negatif dengan pengeluaran untuk makanan, dalam arti semakin tinggi tingkat pendapatan maka semakin rendah porsi pengeluaran untuk makanan. Dengan demikian, di lokasi 
penelitian masih ditemui rumah tangga petani dengan pangsa pengeluaran yang cukup tinggi yang berarti rumah tangga petani tersebut belum sejahtera. Usahatani polikultur terintegrasi sesungguhnya merupakan salah satu model usahatani yang mengusahakan lebih dari satu komoditas, memperhitungkan konsep meminimalkan risiko, meningkatkan produksi dan keuntungan.

Namun demikian, usaha ini belum dikelola secara optimal oleh petani karena berbagai keterbatasan yang ada, diantaranya adalah pada umumnya merupakan petani kecil, luas lahan sempit, modal terbatas dan sering tidak memiliki pengalaman dan pelatihan atau latar belakang bekerja dengan ternak. Selain itu, latar belakang pendidikan formal petani pada umumnya rendah serta dukungan kelembagaan yang juga lemah.

Pola tanam usahatani polikultur terintegrasi dilaksanakan oleh petani dengan berbagai keterbatasannya yang ada pada diri mereka, umumnya memiliki tingkat produktivitas yang rendah. Hal ini bisa dilihat diantaranya dari produktivitas tanaman kakao yang hanya mencapai 0,84 ton per ha padahal potensi produksi kakao dapat mencapai 2 ton biji kering/ha/tahun. Demikian juga dengan tanaman kelapa, Bursatriannyo (2016) jumlah buah/pohon/tahun yang dapat dihasilkan tanaman kelapa adalah sebanyak 75 butir, sementara itu petani hanya mencapai 43 butir buah kelapa/pohon/tahun. Tanaman kopi menurut Tim Tani Karya Mandiri (2010) dapat menghasilkan sebanyak $0,5-5 \mathrm{~kg}$ biji kopi. Produktivitas yang dicapai petani hanya $0,5 \mathrm{~kg}$ biji kopi. Oleh karena itu, diperlukan upaya untuk meningkatkan produksi dan produktivitas usahatani polikultur terintegrasi dalam upaya meningkatkan kesejahteraan petani.

\section{Nilai Tukar Pendapatan Rumah Tangga Pedesaan (NTPRTP)}

Konsep Nilai Tukar Pendapatan Rumah tangga Pedesaan (NTPRP) dapat digunakan untuk mengukur kesejahteraan yang merupakan perbandingan antara pendapatan total rumah tangga dengan pengeluaran total rumah tangga. Pendapatan total rumah tangga merupakan penjumlahan dari seluruh hasil produksi komoditas pertanian yang dihasilkan petani baik dari tanaman polikultur (tanaman kehutanan, perkebunan, hortikultura maupun tanaman pangan) serta dari usaha ternak, ditambah nilai berburuh tani, nilai dari 


\section{KESEJAHTERAAN PETANI PELAKU USAHATANI POLIKULTUR TERINTEGRASI \\ DI KABUPATEN TASIKMALAYA \\ Rina Nuryati, Lies Sulistyowati, Iwan Setiawan, Trisna Insan Noor}

berburuh non pertanian, pendapatan dari anggota keluarga dan lainnya. Sedangkan pengeluaran petani merupakan penjumlahan dari pengeluaran untuk konsumsi rumah tangga dan pengeluaran untuk biaya produksi.

NTP merupakan hubungan antara hasil pertanian yang dijual petani dengan barang dan jasa lain yang dibeli oleh petani. Secara konseptual, NTP mengukur kemampuan tukar barangbarang (produk) pertanian yang dihasilkan petani dengan barang atau jasa yang diperlukan untuk memproduksi barang pertanian.

Tabel 4. Nilai Tukar Pendapatan Rumah Tangga Pedesaan (NTPRTP) $\mathrm{Kab}$. Tasikmalaya

\begin{tabular}{llr} 
& & Tasikmalaya \\
\hline A & Pendapatan & $14.449 .599,03$ \\
\hline & 1. Pertanian & $10.514 .780,44$ \\
\hline & 2. Non Pertanian & $3.934 .818,59$ \\
\hline B & Biaya Produksi & $1.436 .648,13$ \\
\hline C & Konsumsi & $13.739 .551,65$ \\
\hline & Pangan & $6.516 .118,32$ \\
\hline & Non Pangan & $7.223 .433,33$ \\
\hline D & Total Pengeluaran & $13.739 .551,65$ \\
\hline & Nilai Tukar & \\
E Pendapatan & \\
Terhadap & 10,06 \\
\hline & \\
1. Biaya Produksi & \\
\hline $\begin{array}{l}\text { 2. Konsumsi } \\
\text { Pangan }\end{array}$ & 2,22 \\
\hline 3. Konsumsi Non & \\
Pangan & 2,00 \\
\hline 4. Total Konsumsi & 1,05 \\
\hline $\begin{array}{l}\text { 5. Total } \\
\text { Pengeluaran }\end{array}$ & \\
\hline
\end{tabular}

Pendapatan rata-rata petani per tahun sebesar Rp 14.449.599,03, pendapatan terbesar diperoleh dari sektor pertanian Rp 10.514.780 (72,77\%) dan pendapatan dari sektor non pertanian sebesar Rp 3.934.818,59 (27,23\%). Biaya produksi yang dikeluarkan petani untuk membiayai usahatani polikulturnya adalah sebesar $\mathrm{Rp}$ 1.436.648,13 dengan biaya untuk memenuhi kebutuhan konsumsi keluarga sebesar Rp 13.739.551,65. Konsumsi non pangan memerlukan biaya yang lebih besar (Rp 7.223.433,33) dibandingkan dengan biaya pangan ( $\operatorname{Rp} 6.516 .118,32)$.

Nilai tukar pendapatan terhadap biaya produksi mencapai 10,06 , nilai tukar terhadap konsumsi pangan mencapai 2,22 dan nilai tukar terhadap konsumsi non pangan 2,00. Nilai total terhadap total konsumsi dan total pengeluaran mencapai nilai 1,05 .

Rachmat (2013) menjelaskan bahwa nilai tukar pendapatan rumah tangga petani bernilai $>1$ maka berarti petani mengalami surplus, harga produksinya naik lebih besar dari kenaikan harga konsumsi dan biaya produksi. Pendapatan naik lebih besar dari pengeluarannya. Nilai tukar rumah tangga $=1$, berarti petani mengalami impas/break even. Kenaikan/penurunan 
harga produksi sama dengan persentase kenaikan/penurunan harga konsumsi dan biaya produksi, tingkat kesejahteraan petani tidak mengalami perubahan. Nilai tukar pendapatan rumah tangga petani terhadap total konsumsi dan total pengeluarannya $<1$ yang berarti petani mengalami defisit. Harga produksinya naik lebih kecil dari kenaikan harga konsumsi dan biaya produksi. Tingkat kesejahteraan petani mengalami penurunan dibanding dengan tingkat kesejahteraan petani sebelumnya.

Dengan demikian, petani pelaku usahatani polikultur terintegrasi di Kabupaten Tasikmalaya memiliki nilai tukar pendapatan rumah tangga pedesaan bernilai $>1$, hal ini berarti petani mengalami surplus, harga produksinya naik lebih besar dari kenaikan harga konsumsi dan biaya produksi. Pendapatan naik lebih besar dari pengeluarannya sehingga termasuk pada kategori sejahtera. Meskipun demikian, diperlukan upaya untuk terus dapat meningkatkan pendapatan rumah tangga petani berkenaan dengan hasil tukar komoditas pertanian yang cenderung mengalami penurunan sementara biaya produksi dan keperluan konsumsi pangan dan non pangan terus mengalami peningkatan.
Saleh et al (2000) menjelaskan bahwa faktor harga berpengaruh besar terhadap nilai tukar penerimaan dan nilai tukar pendapatan. Nilai tukar penerimaan dipengaruhi oleh tingkat penerapan teknologi, tingkat serangan hama/ penyakit, musim/cuaca, dan harga (baik harga saprodi maupun harga produk). Nilai tukar subsisten dipengaruhi oleh besarnya tingkat pendapatan usaha pertanian dan tingkat pengeluaran untuk konsumsi pangan.

\section{KESIMPULAN DAN SARAN}

Berdasarkan hasil analisis data dan pembahasan maka dapat disimpulkan sebagai berikut:

a) Pendapatan rumah tangga petani pelaku usaha polikultur terintegrasi bersumber dari sektor pertanian dan sektor non pertanian serta dari pendapatan anggota keluarga. Pendapatan dari sektor pertanian diperoleh dari usahatani polikultur (tanaman kehutanan, perkebunan, hortikultura dan tanaman pangan) dan usaha ternak. Kontribusi pendapatan dari usahaternak lebih besar $(37,99 \%)$ dibandingkan dengan kontribusi sektor pertanian $(35,52 \%)$ dan non pertanian $(26,49 \%)$, serta kontribusi pendapatan anggota keluarga $(7,91 \%)$ terhadap 


\section{KESEJAHTERAAN PETANI PELAKU USAHATANI POLIKULTUR TERINTEGRASI \\ DI KABUPATEN TASIKMALAYA \\ Rina Nuryati, Lies Sulistyowati, Iwan Setiawan, Trisna Insan Noor}

pendapatan rumah tangga petani.

Pendapatan dari sektor pertanian (usahatani polikultur terintegrasi) penyumbang terbesar bagi pendapatan rumah tangga petani. $71,46 \%$ keluarga petani proporsi pendapatan dari sektor pertanian mencapai lebih dari $80 \%$. Sebanyak 63,67 petani di Kabupaten Tasikmalaya menggantungkan hidup sepenuhnya dari sektor pertanian.

b) Pangsa pengeluaran pangan rumah tangga petani masih cukup tinggi, sebanyak 42,19\% keluarga petani melakukan pengeluaran untuk pangannya antara 60-80\% dan lebih dari $80 \%$.

c) Nilai tukar pendapatan rumah tangga petani bernilai $>1$, hal ini berarti petani mengalami surplus, harga produksinya naik lebih besar dari kenaikan harga konsumsi dan biaya produksi. Pendapatan naik lebih besar dari pengeluarannya sehingga termasuk pada kategori sejahtera.

Saran yang dapat disampaikan dari hasil kajian ini adalah: diperlukan upaya untuk terus dapat meningkatkan pendapatan rumah tangga pedesaan melalui pengelolaan usahatani polikultur terintegrasi yang lebih optimal agar produksi dan produktivitasnya meningkat berkenaan dengan hasil tukar komoditas pertanian yang cenderung mengalami penurunan sementara biaya produksi dan keperluan konsumsi pangan dan non pangan terus mengalami peningkatan.

\section{DAFTAR PUSTAKA}

Abdurahman, Ismail dan Sutono. 1997. Dukungan Penelitian Terhadap Pengembangan Pertanian Lahan Kering. Prosiding Lokakarya Nasional Pertanian Lahan Kering di Kawasan Timur Indonesia. Malang 10-12 Oktober 1996. Dewan Pengambangan Kawasan Timur Indonesia.

Agustian, A. dan Ilham, N. 2008. Analisis Proporsi Pendapatan dan Pengeluaran Rumah Tangga Petani Padi Pada Berbagai Ekosistem. Pusat Analisis Sosial Ekonomi dan Kebijakan Pertanian. Departemen Pertanian

Chambers, R. dan Conway, G. 1991. Sustainable rural livelihood: Practical Concepts for 21st Century, IDS Discussion Paper 296: IDS. Institute for Development Studies, Brighton.

Bursatriannyo. 2016. Varietas Unggul Kelapa. Pusat Penelitian dan Pengembangan Perkebunan (Puslitbangbun).

Ellis. 2000. The Determinants of rural livelihood diversification in developing countries. Journal of Agricultural Economic, 51, 289302.

FAO. 2009. FAO Statistics Household Survei Database; International Labour Organization (ILO) and Country Publications. http://www.fao.org/fileadmin/templ ates/ess/documents/food_security_s tatistics. diakses tanggal 27 Januari 2010 
Ilham , N. 2009. Dinamika Kesejahteraan Petani dan Non Petani di Indonesia: Suatu Analisis Makro vs Mikro. Prosiding Seminar Nasional "Dinamika Pembangunan Pertanian dan Perdesaan : Tantangan dan Peluang bagi Peningkatan Kesejahteraan Petani. Penyunting: Suradisastra dkk. Pusat Analisis Sosial Ekonomi dan Kebijakan Pertanian

Andriani, I., Muhammad, H. dan Sarpina. 2012. Potensi Limbah Kulit Kakao Sebagai Peluang Integrasi Dengan Ternak kambing Di Sulawesi Barat. Loka Pengkajian Teknologi Pertanian Sulawesi Barat.

Kusnadi. 2000. Nelayan Strategi Adaptasi dan Jaringan Sosial. Humaniora Utama Press. Bandung.

Siswati, L. dan Nizar, R. 2014. Kesejahteraan Petani Pola Pertanian Terintegrasi tanaman Hortikultura dan Ternak. Jurnal Ilmiah ilmu-ilmu Peternakan Vol. XVII No.1 Mei 2014. Fakultas Pertanian Universitas Lancang Kuning Pekanbaru Riau.

Lisson, S., N. MacLeod, C. McDonald, J. Corfield, B. Pangelly, L. Wirajaswadi, R. Rahman. S. Bahar, R. Padjung, N. Razak, K. Puspadi, Dahlanuddin, Y. Sutaryono, S. Saenong, T. Panjaitan, L. Hadiawati, A. Ash, and L. Brennan. 2010. A participatory, farming system approach to Improving Bali cattle production in the smallholder crop-livestock system of eastern Indonesia. Agricultural Systems 103: 486-497.

McLeod, M.K. dan Rahmiana. 2009. Upland Soils for Crop Production in IndonesiaConstraints and Opportunities. Proceedings Internasional seminar, Upland for Food
Security, November 7-8 2009, Purwokerto

Rachmat, M. 2013. Nilai Tukar Petani: Konsep, Pengukuran dan Relevansinya sebagai Indikator Kesejahteraan Petani. Forum Penelitian Agro Ekonomi 31(2):111-122.

Pakpahan, A. 2011.Pangan dan Kedamaian, http://pikiran rakyat.com/mobile/artikel/pangandan-kedamaian.php. Diakses 12 September 2011.

Pusat Penelitian dan Pengembangan Tanah dan Agroklimat. 2001. Atlas Arahan tata Ruang Pertanian Indonesia skala 1 : 1.000.000. Puslitbangtanak. Bogor. Indonesia. 37 hal. Rachman, A.A. Dariah dan D. Setyorini. Perkembangan Teknologi Pengeloaan Lahan Kering. 2007. Balai Penelitian Tanah. Balai Besar Litbang Sumberdaya Lahan Pertanian. Un publish.

Saleh, C., Susilowati, S. H., dan Rahmat, S. 2000. Studi nilai tukar petani dan nilai tukar komoditas pertanian. Bogor: Pusat Penelitian Sosial Ekonomi Pertanian, Kementerian Pertanian.

Sing and Ratan. 2009. Farming system approach for growth in Indian Agriculture. Lead paper in: National Seminar on Enchancing efficiency of Extension for sustainable agriculture and livestock production, Dec 29-30. Indoan Veterinary Research institute, Izatnagar.

Sudaryanto, I.W. Rusastra dan P. Simatupang. 1999. The Impact of Economic Crisis and Policy Adjusment on Food Crop Development Toward Economic Globalization. Paper Presented on "Rountable Discuccion on Food and Nutrition Task Force I; Food 
and Agriculture" Pra WNPG VII, 8 November 1999. Center For AgroSocio Economic Reseacrh, Bogor.

Sugiarto. 2008. Analisa Tingkat Kesejahteraan Pe tani Menurut Pola Pendapatan dan Pengeluaran Di Perdesaan. Seminar Nasional Dinamika Pembangunan Pertanian dan Perdesaan; Tantangan dan Peluang Bagi Peningkatan Kesejahteraan Petani. Bogor. Pusat Analisis Sosial Ekonomi dan Kebijakan Pertanian Departemen Pertanian.

Sumarti, T. 2007. Kemiskinan Petani dan Startegi Nafkah Ganda Rumah Tangga Pedesaan. Sodality; Jurnal Transdisiplin Sosiologi, Komunikasi dan Ekologi Manusia, 1(2), 100-115.

Susilowati, S.H. dan E. Suryani. 2000. Struktur dan Distribusi Pendapatan Rumah Tangga di Pedesaan Jawa Tengah. Dalam : Rusastra, I.W., A.R. Nurmanaf, S.H. Susilowati, E. Jamal, B. Sayaka (Eds). Prosiding
Prespektif Pembangunan Pertanian dan Pedesaan dalam Era Otonomi Daerah. Pp 110-127. Pusat Penelitian Sosial EKonomi Pertanian. Bogor.

Panadji, T. 2013. Politik Pengembanan Lahan Kering dan Reforma Agraria dalam buku Prospek Pertanian Lahan Kering Dalam Mendukung Ketahanan Pangan. Badan Litbang Pertanian.

Turasih dan Wibowo. S.A. 2012.Sistem Nafkah Rumah Tangga Petani Kentang di Dataran Tinggi Dieng. Kasus Desa Karangtengah, Kecamatan Batur Kabupaten Banjarnegara. Propinsi Jawa Tengah. Sodality; Jurnal Sosiologi Perdesaan, 196.

Utomo, W.H. 2012. 2012. Agroforestry: Hidup Layak Berkesinambungan Pada Lahan Sempit. Pusat Studi Pembangunan, LP-IPB. Badan Bimas Ketahanan Pangan. Departemen Pertanian RI. 